\title{
KANANMUNAMASSAN PASTÖROINNISTA JA JÄÄDYTTÄMISESTÄ
}

\author{
Merimaija Holopainen
}

Saapunut 17. 3. 1971

\author{
Maitotaloustuotteiden tarkastuslaitos, Helsinki \\ THE PASTEURIZATION AND COOLING OF LIQUID EGG
}

\author{
Merimaija Holopainen
}

\begin{abstract}
According to overseas studies the beating time of liquid egg is prolonged and the specific volume of foam is reduced through pasteurization and cooling. As simultaneously, however, the foam stability is improved, the volume of ready made cakes will be equal irrespective of the handling of the raw material.

In the above studies of liquid egg, no significant differences were established either in the beating time of shell egg and pasteurized and raw liquid egg or in the foam specific volume or the foam stability. The freezing of liquid egg has reduced the foam specific volume, on the other hand it has improved significantly the foam stability. When pasteurized and frozen liquid egg was stored in $-25^{\circ} \mathrm{C}$, the foam specific volume was reduced further after three months' storing and after eight months it was reduced to about half of the foam specific volume of the pasteurized fresh liquid egg. In unpasteurized liquid egg this property remained unchanged.

Judging by the microbiological studies the unpasteurized liquid egg can be rated as a very doubtful product hygienically, whereas the pasteurized liquid egg stored in $+6^{\circ} \mathrm{C}$ can be regarded as harmless for human health as late as on the 5 th day from the date of manufacturing. Nowadays a storage temperature of $+4^{\circ} \mathrm{C}$ is maintained which also secures the keeping quality of the product according to information in the literature.

The $0.05,0.1$ or 0.2 per cent weight increases of sodium bentzoate (calculated in bentzoic acid) did not have any effect on the keeping quality of the product when stored in $+6^{\circ} \mathrm{C}$.
\end{abstract}

Vuonna 1967 aloitettiin maassamme pastöroidun munamassan valmistus. Aluksi kokeiltiin pienien erien pastörointia patapastöörissä. Noin vuoden kuluttua siirryttiin suurempiin eriin ja levypastörointiin. Munamassan valmistamisen syyt ovat lähinnä seuraavat:

a) Munien laatutarkkailussa erotetaan suuri määrä munia siitä syystä, että niiden kuorissa on säröjä. Lisäksi valkeaan Leghorn-rotuun kuuluvat kanat tulevat varhain sukukypsiksi ja munivat pitkään ja paljon pieniä munia. Viime vuonna käytettiin pastöroidun massan valmistukseen $\mathrm{n}$. 2.5 milj. kg särökuorisia tai pieniä munia. 
b) Munien tuotanto on suurimmillaan marras-tammikuussa. Tuotannon ja toisaalta kysynnän vaihtelua voidaan tasoittaa massaa valmistamalla koska se pastöroituna ja jäädytettynä on helposti varastoitavissa.

c) Elintarviketeollisuus, joka käyttää suuria munamääriä tarvitsee massaa käyttäessään vain vähän varastotilaa, välttyy munien särkymisvaaralta ja joukossa mahdollisesti olevan pilaantuneen tavaran säilyttämiseltä. Munia ei myöskään tarvitse rikkoa samoissa tiloissa joissa tuotteita valmistetaan. Tällöin vältytään likaisten kuorien aiheuttamalta kontaminaatiovaaralta.

Käsillä oleva kirjallisuuskatsaus ja tutkimustyö pyrkii selvittämään munamassassa pastöroinnin ja jäädyttämisen aikana tapahtuvia muutoksia, jotka vaikuttavat massan käyttöominaisuuksiin. Maassamme on otettu käytäntöön korkein ulkomailla suositeltu pastörointilämpötila ja koska suomalaisen kananmunan koostumus jossakin määrin poikkeaa ulkomailla saaduista tuloksista (KYтi et al. 1968 a ja b) on katsottu aiheelliseksi suorittaa tutkimuksia maassamme pastöroiduista munamassoista. Näin saatuja tuloksia ulkomaisiin tutkimustuloksiin verrattaessa saadaan lähtökohta mahdollisia teknillisiä parannuksia suunniteltaessa.

\section{Vaahdonmuodostuskyky}

Munan tärkein leivontaominaisuus on sen vaahdonmuodostuskyky, joka on riippuvainen munien proteiinikoostumuksesta. Vaahdonmuodostusta tutkittaessa on pyritty selvittämään proteiinin eri komponenttien merkitystä, jotta samalla saataisiin tietoja pastöroinnin aiheuttamista muutoksista. PARKINSON (1967) esittää tutkimuksessaan kananmunan proteiinikoostumuksen prosentteina munan sisällöstä seuraavasti:

$\begin{array}{llllll}\text { ovalbumiini } & 4.1 \% & \text { lysotsyymi } & 0.3 \% & \text { lipovitelleniini } & 2.3 \% \\ \text { konalbumiini } & 1.0 \% & \text { ovomukiini } & 0.1 \% & \text { fosvitiini } & 1.0 \% \\ \text { ovomukoidi } & 0.8 \% & \text { flavoproteini } & 0.06 \% & \text { livetiinit } & 0.7-1.8 \% \\ \text { globuliinit } & 0.6 \% & \text { lipovitelliini } & 3.0 \% & & \end{array}$

Näistä on valkuaisen sisältämiä komponentteja tutkittu eniten. Seuraavaan on kerätty vaahdonmuodostukseen eniten vaikuttavat yhdisteet sekä selostettu niiden mahdollista osuutta leivonnassa (KNight et al. 1967, Garibaldi et al. 1968, NaKamura 1966).

Ovalbumiini, jota munassa on eniten säilyttää tuotteen rakenteen huokoisena saostumalla paistamisen aikana liukenemattomiksi yhdisteiksi vaahtokuplien pinnalle.

Ovomukiinin kuitujen pituus lyhenee vatkauksen aikana. Tämä ilmeisesti parantaa valkuaisen vatkautuvuutta. Ovomukiinin tärkein osuus leivonnassa on kuitenkin sen vaahtoa stabiloiva ominaisuus. Tämä ominaisuus johtuu sen korkeasta viskositeetista sekä sen saostumisesta vaahtokuplien pinnalle. Ovomukiinin ja lysotsyymin saostuminen ja siitä johtuva aggregaattien muodostuminen ennen vatkauksen alkamista huonontaa selvästi valkuaisen vatkautuvuutta.

Globuliinien vaikutuksesta vatkattavan valkuaisen tilavuus suurenee, muodostuu pieniä kuplia ja rakenteesta tulee pehmeä. 
Munamassoja pastöroitaessa on lämpötila pidettävä suhteellisen alhaisena ja kestoaika lyhyenä saostumisen välttämiseksi. Saostuminen johtuu ilmeisesti siitä, että proteiinimolekyylissä olevien polypeptidien väliset heikot sidokset särkyvät tai muuttavat luonnettaan, josta saattaa olla seurauksena molekyylien liittyminen toisiinsa aggregaateiksi. Näitä muutoksia lähinnä munamassan pastörointia silmällä pitäen ovat selostaneet ja tutkineet Lineweaver ja Cunningham (1964), Reinke ja Baker (1966), Parkinson (1966 ja 1967), Garibaldi et al. (1968) sekä Palmer et al. (1969).

Ovalbumiini säilyy muuttumattomana $65^{\circ} \mathrm{C}$ :ssa $30 \mathrm{~min}$ :in ajan kun se on vesiliuoksena, jonka happamuusaste on $\mathrm{pH}$ 6.5-7.0. Myös ovomukoidi ja lysotsyymi ovat suhteellisen kestäviä lämpökäsittelyyn nähden. Sensijaan konalbumiini hyytyy herkästi, ellei läsnä ole tarpeeksi rautaa, joka yhtyessään konalbumiiniin muodostaa lämpöä kestävän yhdisteen. Tästä syystä valkuaismassaa valmistettaessa koaguloituminen tapahtuu herkästi, koska valkuaisessa ei ole tarpeellista rautamäärää. Munamassan rautapitoisuus on normaalisti riittävä. Valkuaismassan lämpökäsittelyssä on voitu käyttää korkeampia lämpötiloja lisäämällä massaan $50 \mathrm{ppm}$ ferrikloridia. Sama vaikutus on saatu aikaan lisäämällä 25 ppm aluminiumsulfaattia.

Proteiiniosan entsyymien lämpöherkkyyteen perustuen on kehitetty koe pastöroinnin tehokkuuden määrittämiseksi. $\alpha$-amylaasin on todettu tuhoutuvan kun munamassaa kuumennetaan 2.5 min:n aika $64.5^{\circ} \mathrm{C}$ :ssa. Tämä tuhoutuminen on helposti määritettävissä tärkkelystestillä.

Valkuaismassan herkän saostumisen johdosta sen pastörointilämpötilaksi suositellaan $55-56^{\circ} \mathrm{C}$ ja kestoaikaa 2 min. Keltuaismassalle suositellaan lämpötiloja $62.2-64.4^{\circ} \mathrm{C}$ ja kestoaikaa 3.5 min. Pastörointilämpötilojen $63.3^{\circ} \mathrm{C}$ ja $64.4^{\circ} \mathrm{C}$ on todettu aiheuttavan keltuaisessa lievää viskositeetin nousua, joka ei kuitenkaan ole vaikuttanut keltuaismassan käyttöominaisuuksiin.

Munamassaa valmistettaessa muodostuu valkuaisen ja keltuaisen proteiinien kesken ilmeisesti kompleksiyhdisteitä, jolloin proteiiniosan luonne jossakin määrin muuttuu. Munamassan viskositeetin on todettu kohoavan hitaasti, mutta tasaisesti lämpötilan kohotessa $56^{\circ} \mathrm{C}$ :sta $60^{\circ} \mathrm{C}$ :een ja vähenevän välillä $67-68^{\circ} \mathrm{C}$, jossa vaiheessa muodostuu runsaasti saostumaa. Lämpötilan kohotessa edelleen viskositeetti kohoaa jälleen kunnes saostuminen tapahtuu täydellisenä juuri ennenkuin on saavutettu lämpötila $73^{\circ} \mathrm{C}$. Varsinaisissa pastörointiin suositelluissa lämpötiloissa $61.1^{\circ} \mathrm{C}$ :sta $64.4^{\circ} \mathrm{C}$ :een on kokeita tehty kestoaikojen vaihdellessa 0.5 minuutista 14 minuuttiin. Tällöin on todettu viskositeetin lisääntyvän samassa lämpötilassa lineaarisesti ajan suhteen. Lisäys on kuitenkin sitä nopeampaa mitä korkeampi lämpötila on kyseessä.

Lineweaver ja Cunningham (ref. Parkinson 1966) ovat esittäneet tärkeimmät munamassan lämmönkestävyyttä lisäävät tekijät seuraavasti:

a) Keltuaisen tulee sisältää tarpeellinen määrä rautaa, jotta valkuaisen konalbumiini sitoutuisi

b) Kananmunan $\mathrm{pH}: \mathrm{n}$ tulee olla rajoissa 7.5-7.8, jotta lysotsyymi, ovalbumiini ja ovomukoidi eivät saostuisi.

Myös jäädyttäminen vaikuttaa munamassan rakenteeseen. Sekä keltuais- että munamassassa on jäädyttämisen todettu lisäävän viskositeettia. Säilytettäessä pastöroitua 
massaa jäädytettynä, se saa sulaessaan helposti »rikkoutuneen» tai »erottuneen» ulkonäön. Homogenoitaessa massan tasaisuus palautuu. Säilytyksen aikana muodostuu ilmeisesti palautuvia aggregaatteja yhdestä tai useammasta kananmunan aineosasta. Nämä aggregaatit särkyvät kuitenkin, jos massaa sulattamisen aikana sekoitetaan tai jos massa sulatuksen jälkeen homogenoidaan. On kuitenkin ilmeistä, että aggregaattien muodostuminen aiheuttaa osittaisen emulsion rikkoutumisen, jolloin öljyä vapautuu, ja massan leipoutumisominaisuudet huononevat.

Jäädyttämisen ja pastöroinnin aiheuttamia muutoksia ovat KALOYERAs et al. (1962) poistaneet lisäämällä massoihin $500 \mathrm{ppm}$ erilaisia proteolyyttisiä entsyymejä, joista voidaan mainita fikiini, bromeliini ja papaiini.

\section{Pastöroidun massan leivontaominaisuudet}

KNIGHT et al. (1967) ovat määrittäneet vaahdon ominaisvolyymin (ml vaahtoa/g massaa) sekä raakamassalle että eri lämpötiloissa pastöroiduille massoille seuraavasti:

\begin{tabular}{llrl} 
& \multicolumn{2}{l}{ lämpötila ja aika } & $\mathrm{ml} / \mathrm{g}$ \\
raakamassa & & & 3.82 \\
pastöroitu massa & $63.0^{\circ} \mathrm{C}$ & $2.5 \mathrm{~min}$ & 3.94 \\
pastöroitu massa & $63.3^{\circ} \mathrm{C}$ & $2.5 \mathrm{~min}$ & 3.18 \\
pastöroitu massa & $63.9^{\circ} \mathrm{C}$ & $2.5 \mathrm{~min}$ & 3.29 \\
pastöroitu massa & $64.4^{\circ} \mathrm{C}$ & $2.5 \mathrm{~min}$ & 3.37
\end{tabular}

Pastörointilämpötilan kohotessa yli $63^{\circ} \mathrm{C}$ alenee näiden tutkimusten mukaan vaahdon ominaisvolyymi selvästi.

Mrller ja Winter (1950) ovat tutkineet munamassojen ja munien vatkaamiseen tarvittavia aikoja. Tutkimusten tulokset osoittavat, että pastöroitujen ja jäädytettyjen massojen vatkautumiseen tarvittava aika on ollut noin $8 \%$ pitempi kuin munien vatkautumiseen tarvittava aika ja noin $17 \%$ pitempi kuin käsittelemättömän massan vatkautumiseen tarvittava aika.

Kuten edellä on selvitetty, on tutkimusten perusteella todettu vatkautuvuusajan pitenevän ja vaahdon tilavuuden vähenevän kun munamassaa pastöroidaan tai jäädytetään. Toisaalta näiden käsittelyjen on todettu lisäävän vaahdon kestävyyttä. Tämä todettiin (MILler ja Winter 1950) valumiskokeella, tilavuuseroina vaahdon ja valmiin kakun välillä sekä vertaamalla valmiiden kakkujen volyymejä toisiinsa. Valumiskokeessa seisotettiin punnittu määrä valmista vaahtoa tunnin ajan ja mitattiin tänä aikana valuneen nesteen määrä millilitroina. Kuten seuraavasta numeroasetelmasta voidaan havaita, ei pastöroinnilla ollut vaikutusta kakun tilavuuteen. Vaikka käsitellyistä massoista saatiin vähäisempi määrä vaahtoa, sen säilyvyys paistettaessa oli selvästi munista tehtyä vaahtoa parempi. Myöskään värissä, kiinteydessä, kosteudessa tai maussa ei havaittu eroja eri kakkujen välillä.

kuorimunat
pastöroimaton massa
pastöroitu $60-61^{\circ} \mathrm{C}: s s a$
pastöroitu $61-62.2^{\circ} \mathrm{C}: s s a$
pastöroitu $62.2-63.3^{\circ} \mathrm{C}: s s a$
$100 \mathrm{~g}$ :sta vaahtoa valmiiden kakku- vaahdon ja kakun tunnin aikana va- jen tilavuudet ominaispainojen lunut nestemäärä $\mathrm{ml} \quad \mathrm{ml}$ erotus

$\begin{array}{lll}69.8 & 2160 & 0.136 \\ 19.5 & 2206 & 0.123 \\ 15.4 & 2199 & 0.125 \\ 25.6 & 2196 & 0.118 \\ 15.1 & 2186 & 0.118\end{array}$


Heller et al. (1962) antoivat yhdeksän leipomon verrata keskenään pastöroimatonta massaa $64.4^{\circ} \mathrm{C}$ :ssa 2.5 min:n ajan pastöroituun ja homogenoituun massaan. Leipomot valmistivat kummastakin massasta rinnakkain erilaisia konditoriatuotteita. Tulokset olivat osittain ristiriitaisia, mutta mitään selvää eroa massojen paremmuudesta toisiinsa verrattuna ei havaittu.

Sugrhara et al. (1966) ovat todenneet ettei pastöroinnilla $62.8^{\circ} \mathrm{C}$ :seen $(3.5 \mathrm{~min})$ ole ollut mitään vaikutusta jäädyttämättömästä massasta valmistettuihin kakkuihin. Jäädytetystä pastöroidusta massasta saatiin sensijaan kakku, jonka tilavuus oli kontrollikakun tilavuutta n. $3 \%$ pienempi. Pastöroinnin ja homogenoinnin yhteisvaikutus pienensi jäädyttämättömästä munamassasta valmistettujen kakkujen tilavuutta, mutta paransi jäädytetystä pastöroidusta massasta valmistetun kakun tilavuuden samaan suuruusluokkaan kuin jäädytetystä massasta tehdyllä kakulla.

Neljän vuorokauden säilytys $3.3-4.4^{\circ} \mathrm{C}$ :ssa ei aiheuttanut mitään muutoksia pastöroidussa massassa (KNIGHT et al. 1967). Samat tutkijat säilyttivät sekä pastöroitua että pastöroimatonta massaa jäädytettynä $-10^{\circ} \ldots-11^{\circ} \mathrm{C}$ :ssa. Pastöroimaton massa säilyi näissä olosuhteissa laadultaan muuttumattomana kaksi vuotta, pastöroitu massa sensijaan vain n. 30 viikkoa. Tutkijat totesivat pastöroidun massan vaahdonmuodostuskyvyn huononevan jo 20 viikon jälkeen, mutta valmiin kakun tilavuudessa alkoi ilmetä pienenemistä vasta mainitun 30 viikon kuluttua.

\section{Munamassan mikrobiologiaa}

Kun munamassaa valmistetaan suurissa määrissä elintarviketeollisuuden raakaaineeksi on sen hygieenistä laatua tarkkailtava. Munia rikottaessa pääsee kuorista massan joukkoon runsaasti mikrobeja, jotka lisääntyvät nopeasti. Ehjänä kananmuna on suhteellisen säilyvä luonnontuote. Ensinnäkin kuori ja sen pinnalla oleva kutikula hidastavat mikrobien sisäänpääsyä. Munaan päästyään mikrobit joutuvat ensin kosketukseen valkuaisen kanssa. Tämä sisältää runsaasti mikrobien kasvua estäviä yhdisteitä. Vasta päästessään keltuaiseen mikrobit pystyvät lisääntymään nopeasti. Massaa valmistettaessa keltuainen sekoittuu valkuaiseen, jolloin jälkimmäisen mikrobikasvua estävien tekijöiden vaikutus heikkenee. Vaikka massa välittömästi valmistuksen jälkeen vietäisiin jäädytettäväksi, kestää sekä massan valmistus että sen jäätyminen siksi kauan, että bakteerien kokonaismäärä ehtii kohota huomattavasti. MAJEwsKA (1962) on tưtkinut 514 valmistamisen jälkeen $-10^{\circ} \mathrm{C}$ :ssa jäädytettyä massaa. Jäätyminen kesti 48 tuntia. Bakteerien kokonaismäärät vaihtelivat näissä massoissa 640000 -900 000 pesäkettä/ml. Kun vastaavat massat pastöroitiin vaihteli bakteerien kokonaismäärä $1700-2700$ pes./ml. Samoista massoista on tekijä esittänyt koliryhmän bakteereja koskevat tutkimustulokset seuraavasti:

$\begin{array}{lrrrrrrr}\text { pastöroitu massa } & & 1.0 & 0.1 & 0.01 & 0.001 & 0.0001 & 0.00001 \\ \quad \text { huhtikuu } & 275 & 2.5 & & & & & \\ \text { toukokuu } & 251 & 16.3 & & & & & \\ \quad \text { kesäkuu } & 199 & 29.6 & & & & & \\ \begin{array}{l}\text { pastöroimaton massa } \\ \text { huhtikuu }\end{array} & 132 & & 31.8 & 32.5 & 26.5 & 9.0 & \\ \quad \text { toukokuu } & 257 & & 0.3 & 6.6 & 17.1 & 50.1 & 25.6 \\ \text { kesäkuu } & 125 & & 1.6 & 6.4 & 24.0 & 29.6 & 38.4\end{array}$


Tarkasteltaessa munamassan mikrobiologista laatua, ovat tutkijat sitä mieltä, että pastörointi tuhoaa yli $99 \%$ massan mikrobistosta silloinkin kun käytetään pastörointilämpötilaa $60-61^{\circ} \mathrm{C}$ ja kestoaikaa $4 \mathrm{~min}$. Näin ollen antaa pastörointi erinomaisen suojan mikrobeja vastaan. Lisäksi tällainen massa säilyy sekä aistinvaraisesti että mikrobiologisesti arvostellen käyttökelpoisena vähintään 6 vrk kun sitä säilytetään $3.3^{\circ} \mathrm{C}$ :ssa ja vähintään 5 vrk kun sitä säilytetään $4.4^{\circ} \mathrm{C}$ :ssa (Wood ja Young 1969).

Maissa, joissa munamassoille on määrätty pastörointipakko, tämä on aiheutunut lähinnä salmonellavaaran olemassaolosta. Salmonellatutkimuksia onkin suoritettu erittäin runsaasti varmuusmarginaalin selville saamiseksi.

MAJEwska (1962) on esittänyt tietoja puolalaisten massojen salmonellaesiintymistä. Heillä käytössä oleva pastörointimenetelmä on seuraava: $+10^{\circ} \mathrm{C}$ :ssa oleva munamassa kuumennetaan $67-68^{\circ} \mathrm{C}$ :een ja jäähdytetään välittömästi takaisin $+10^{\circ} \mathrm{C}$ :seen. Käsittely kestää 3.6 min. Tutkimuksissa oli 514 raakamassaa, joista 77 sisälsi ryhmää Salmonella gallinarum-pullorum ja yksi $S$. typhimuriumia. Pastöroiduista näytteistä $(725 \mathrm{kpl})$ tehdyt salmonellakokeet olivat kaikki kielteisiä.

Heller et al. (1962) ovat lisänneet munamassaan Salmonella gallinarumin ja S. typhimuriumin puhdasviljelmäseosta siten, että näiden määrä on ollut 400000 bakt./ml. Tämän jälkeen massaa pastöroitiin 2.5 min. eri lämpötiloissa. Todettiin, että $62.8^{\circ} \mathrm{C}$ :een pastöroinnilla käsitellystä massasta otettu $50 \mathrm{ml}: \mathrm{n}$ näyte oli kielteinen salmonellojen suhteen.

SugrharA et al. (1969) ovat määritelleet hygieenisesti turvalliseksi sellaisen pastörointimenetelmän, jossa lisätyn bakteerimäärän tuhoutumiskertoimeksi saadaan luku $10^{7}$. S. typhimuriumille he saivat $60^{\circ} \mathrm{C}$ :ssa kahden minuutin kestoajalla tuhoutumiskertoimeksi $10^{8}$. Sensijaan $S$. senftenberg $775 \mathrm{~W}$ :n kertoimeksi saatiin vain $10^{4}-10^{5}$ silloinkin kun käytettiin lämpötilaa $64.4^{\circ} \mathrm{C}$ ja kestoaikaa $3.5 \mathrm{~min}$.

GARIBALDI et al. (1969) ovat lähteneet salmonellatutkimuksissaan tarkastelemaan miten paljon lukumääräisesti näitä mikrobeja esiintyy massoissa. Heidän mielipiteensä mukaan tutkimukset, joissa todetaan ainoastaan näytteiden positiivisuus eivät sinänsä vielä sano mitään näytteiden vaarallisuudesta eivätkä myöskään riitä selvittämään pastöroinnille asetettavia vaatimuksia. He ovat käsitelleet sekä muiden tutkijoiden aineistoja että omien tutkimustensa tuloksia. Tällöin 156:ssa pastöroimattomassa munamassassa ja 131 :ssä pastöroimattomassa valkuaismassassa oli 100 salmonella positiivista näytettä. Jakautuma salmonellojen lukumäärän perusteella oli positiivisissa näytteissä seuraava:

näytemäärä bakteerien todennäköinen lukumäärä

(MPN) millilitrassa massaa

$\begin{array}{rlc}86 & \mathrm{kpl} & \text { alle } 1 \\ 10 & \mathrm{kpl} & 1.4-2.9 \\ 1 & \mathrm{kpl} & 5.3 \\ 2 & \mathrm{kpl} & 24 \\ 1 \mathrm{kpl} & 110\end{array}$

Samalla he pyrkivät selvittämään bakteerien kokonaismäärän suhdetta salmonellaesiintymiin. Tällöin he toteavat, että massat joissa bakteerien kokonaismäärät ovat suuret $\left(10^{6}-6 \times 10^{7} \mathrm{pes} / \mathrm{g}\right)$ myös salmonellojen esiintymisvaara on suuri. Toisaalta eivät kuitenkaan massat joiden bakteerien kokonaismäärä on alhainen (alle $10^{5} \mathrm{pes} / \mathrm{g}$ ) anna täyttä varmuutta siitä, etteikö salmonelloja voisi esiintyä. Munamassan pastörointimini- 
min vaatimusta $60^{\circ} \mathrm{C}$ kestoajalla 3.5 min verrataan näytteistä saatuihin salmonellamääriin jolloin todetaan, että salmonellojen esiintymismahdollisuus yhdessä g:ssa pastöroitua massaa on 1:5000 000 silloinkin kun lähdetään suurimmasta todetusta raakamassan salmonellamäärästä. Voimakkaasti lämpöäkestävää $S$. senftenberg $775 \mathrm{~W}$ :tä ei tutkijoiden mukaan ole pystytty eristämään munista senjälkeen kun se vuonna 1940 eristettiin ensimmäisen kerran. Näin ollen ei liene asiallista asettaa pastörointivaatimuksia tämän bakteerin mukaan. MAJEwska (1962) on samansuuntaisesti todennut yleisimmiksi munamassoista löydetyiksi salmonelloiksi seuraavat: $S$. thompson, $S$. aberdeen, ryhmä $S$. gallinarum-pullorum ja $S$. typhimurium.

GARIBALDI et al. (1969) ovat esittäneet neljä mahdollisuutta salmonellojen esiintymiselle pastöroiduissa massoissa:
a) pastörointia ei ole hoidettu suositusten mukaisesti.
b) massassa esiintyy erittäin lämpöäkestäviä salmonella-lajeja.
c) salmonelloja on massassa erittäin runsaasti, joka saattaa johtua massan väärästä käsittelystä mu- nien rikkomisen jälkeen tai massan pitkäaikaisesta säilyttämisestä ennen pastörointia.
d) jälkitartunta.

Kuitenkin voidaan sanoa näiden neljän mahdollisuuden olevan hyvin harvinaisia. Edellä mainitut tutkijat ovat v. 1968 löytäneet 1100 pastöroitua massaa tutkittuaan vain yhdestä näytteestä salmonelloja.

\section{Omat tutkimukset}

Tutkimusten tarkoituksena oli selvittää pastöroidun munamassan käyttöominaisuuksia. Koska ulkomaisten tutkimusten perusteella voidaan todeta vatkautuvuuden, vaahdon ominaisvolyymin sekä vaahdon säilyvyyden antavan hyvän kuvan munan leivontaominaisuuksista otettiin nämä ominaisuudet tarkastelun kohteiksi. Koesarjoja oli kaksi. Ensimmäisessä tutkittiin edellä mainittujen kokeiden lisäksi massan mikrobiologista laatua sekä massan säilyvyyttä $6^{\circ}$ :ssa sekä bentsoehappoa lisäämällä että ilman lisäystä. Toisessa koesarjassa tutkittiin jäädytettynä säilyttämisen vaikutusta massaan.

\section{Tutkimusmenetelmät}

Vatkautuvuuskoe: Ensimmäisessa koesarjassa vatkausaika oli 7 min (3 min nopeudella 180 kierrosta/min ja 4 min nopeudella 240 kierrosta/min). Toisessa koesarjassa vatkausaika oli 3 min nopeudella 950 kierrosta/min. Lämpötila kummassakin oli $20^{\circ} \mathrm{C}$. Vaahdon säilyvyys: vaahto punnittiin suodatinpaperilla varustettuun Büchner-suppiloon (halkaisija $12 \mathrm{~cm}$ ). Vaahdon annettiin seisoa yhden tunnin ajan, jonka jälkeen mitattiin vaahdosta valuneen nesteen määrä sekä laskettiin tämän nesteen määrä 100 vaahtogrammaa kohti.

Mikrobiologiset tutkimukset suoritettiin samojen menetelmien mukaan kuin kananmunien mikrobiologista laatua käsittelevissä tutkimuksissa (KYTr et al. 1968 d). Kuivaaineen ja lipidipitoisuuden määritysmenetelmät olivat samat kuin kananmunan kemiallista koostumusta käsittelevissä tutkimuksissa (KYTı et al. 1968 a). 
Kananmunamassojen käyttöominaisuudet ja säilyvyys

Ensimmäinen koes a rja. Materiaalina olivat munat sekä vastaavista munaeristä valmistettuina viisi raakamassaa, kolme levypastöörissä pastöroitua massaa (lämpötila $64.5^{\circ} \mathrm{C}$, kestoaika $3.5 \mathrm{~min}$ ) ja kaksi patapastöörissä pastöroitua massaa (nousuaika $20 \mathrm{~min}$, korkein lämpötila $64.5^{\circ} \mathrm{C}$ ). Tässä koesarjassa käytetyn sähkövatkaimen pienestä kierrosluvusta johtuen jouduttiin käyttämään neljä minuuttia pitempää vatkausaikaa kuin toisessa koesarjassa. Kaikki raaka-aineet vatkautuivat kuitenkin samassa ajassa, joten saman koesarjan puitteissa ei vatkausaikoja tarvinnut muuttaa.

Munista, raakamassoista ja pastöroiduista massoista valmistettujen vaahtojen ominaisvolyymeissä ei ollut eroavuuksia. Rinnakkaiskokeiden ja eri raaka-aineiden vaihtelut olivat rajoissa $3.9-4.1 \mathrm{ml}$ vaahtoa/g munaa. 6 vrk:n $6^{\circ} \mathrm{C}$ :ssa tapahtunut säilytys ei vaikuttanut millään tavoin vatkautuvuuteen tai vaahdon ominaisvolyymiin.

Vaahdon säilyvyyttä tarkasteltaessa todettiin patapastöörissä valmistetusta massasta valuneen hieman vähemmän nestettä $(76 \mathrm{ml})$ kuin muista $(80 \mathrm{ml})$. Pastöroitujen massojen haju ja maku säilyivät hyvinä kuuden vrk:n ajan, raakamassoissa vain vuorokauden. Hyvänä säilyi myös pastöroitujen massojen kiinteys, joka raakamassoissa jo $1-2$ vrk:n kuluttua alkoi olla vetinen. Samoin säilyi pastöroitujen massojen $\mathrm{pH}$ rajoissa 7.67.9, kun se raakamassoissa kuuden vuorokauden kuluttua oli laskenut välille $\mathrm{pH} 6.3-6.5$.

Toin en k o s a r ja. Materiaalina olivat munat, pastöroimaton massa ja levypastöörissä pastöroitu massa (lämpötila $64.5^{\circ} \mathrm{C}$, kestoaika $2.5 \mathrm{~min}$ ). Massat säilytettiin $500 \mathrm{ml}: n$ muovipulloissa, koesarja oli seuraava: Ensimmäinen koe valmistusta seuraavana päivänä massoista, jotka oli säilytetty $4^{\circ} \mathrm{C}$ :ssa. Toinen koe valmistuspäivänä jäädytetyistä ja 4 vrk. $-25^{\circ} \mathrm{C}$ :ssa säilytetyistä massoista. Seuraavat kokeet tehtiin valmistuspäivänä jäädytetyistä ja $-25^{\circ} \mathrm{C}$ :ssa $2,3,4,5,6$ ja 8 kuukautta säilytettyinä olleista massoista. Tutkimusten tulokset on esitetty taulukossa 1 .

\section{Tulosten tarkastelua}

Eri pastörointimenetelmät eivät näiden tutkimusten mukaan vaikuttaneet millään tavoin vatkautuvuusaikaan, vaahdon säilyvyyteen eivätkä vaahdon ominaisvolyymiin kun vertailukohteina olivat munat ja raakamassat. Mitkään ominaisuudet eivät myöskään muuttuneet kun massoja säilytettiin 6 vrk $6^{\circ} \mathrm{C}$ :ssa. Nämä tulokset poikkeavat selvästi ulkomaisista tutkimustuloksista. Vertailu on kuitenkin tehtävä varauksellisesti, sillä julkaisuissa ei yleensä ole selostettu vatkaus- ja vaahdonsäilyvyyskokeiden tarkkaa suoritustapaa. Vain Mrller et al. (1950) ovat selostaneet menetelmänsä, joka poikkeaa selvästi näissä tutkimuksissa käytetyistä menetelmistä. He ovat lisänneet $50 \mathrm{~g}$ :aan munaa $10 \mathrm{ml}$ vettä, ja seosta on vatkattu $1 \mathrm{~min}$.

Tehtyjen tutkimusten mukaan vasta jäädyttäminen on vaikuttanut massasta tehdyn vaahdon ominaisvolyymiin ja vaahdon säilyvyyteen. Ominaisvolyymi on laskenut heti jäädyttämisen jälkeen 3.96:sta välille 2.49-2.68. Jäädytettynä säilytetyn pastöroimattoman massan ominaisvolyymi on tämän jälkeen säilynyt tasaisena koko 8 kk kestäneen koesarjan ajan. Sensijaan pastöroidusta massasta valmistetun vaahdon ominaisvolyymi on selvästi huonontunut jo kolmen säilytyskuukauden aikana. Kokeen lopussa se oli vähentynyt noin puoleen jäädyttämättömän massan ominaisvolyymistä. Nämä tulokset vastaavat kirjallisuudesta saatuja tietoja. 


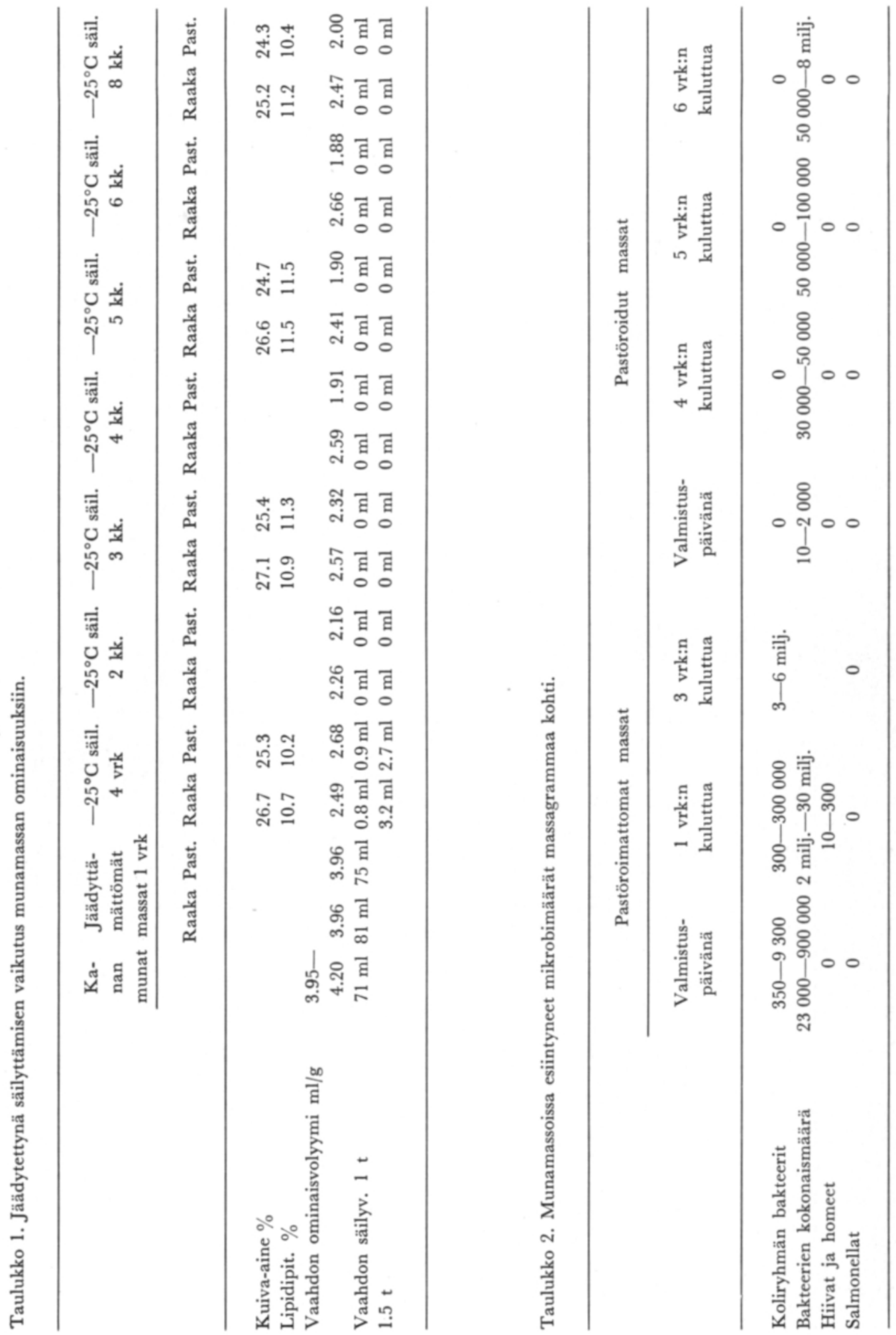


Vaahdon säilyvyyttä jäädyttäminen paransi ratkaisevasti. Vaikka valumisaikaa pidennettiin puolella tunnilla (yht. 1.5 t) valui nestettä ainoastaan niistä massoista, joita oli säilytetty 4 vrk ja niistäkin keskimäärin vain $3 \mathrm{ml}$. Kun tätä tulosta verrataan munista tai jäädyttämättömistä massoista valmistetuista vaahdoista valuneeseen $70-85$ ml:an, on muutos erittäin merkittävä.

Koska kokeessa mukana olleet massat oli pakattu $500 \mathrm{ml}$ :n eriin, tehtiin koesarjan aikana myös kemiallisia tutkimuksia, jotta voitaisiin varmistua siitä, ettei pakkauskohtaisia eroja, kuten kuivumista, ole päässyt syntymään. Lievää haihtumista onkin todettavissa. Pastöroimattomassa massassa, jonka kuiva-ainepitoisuus on kautta linjan korkeampi kuin pastöroidulla massalla, on kuivumista havaittavissa $1.5 \%$-yksikköä 8 sailytyskuukauden aikana. Pastöroidulla massalla muutos on noin $1 \%$-yksikköä.

\section{Mikrobiologiset tutkimukset}

Ensimmäisen koesarjan yhteydessä tehtiin sekä pastöroimattomista että pastöroiduista massoista myös mikrobiologisia tutkimuksia, joiden tulokset ovat taulukossa 2 .

Pastöroimatonta massaa mikrobiologisten tutkimusten valossa tarkasteltaessa voidaan todeta sen olevan hygieenisesti arveluttavaa jo valmistuspäivänä. Sensijaan pastöroitu massa on käyttökelpoista vielä viidentenä päivänä valmistuspäivästä lukien. Mikrobiologisesti arvioiden parhaat massat oli valmistettu patapastöörissä. Tämä on selitettävissä osittain siten, että patapastööria varten valmistettiin pienempi erä massaa kuin levypastööriä varten. Näin ollen patapastööriin tarkoitettu raakamassa joutui pastörointikäsittelyyn nopeasti. Paras pastöroitu massa (valmistuspäivänä 10 pes./g) olikin valmistettu raakamassasta, jossa oli vähiten mikrobeja grammaa kohti. Tämän lisäksi patapastöörin hidas lämpötilannousu varmistaa massassa kauttaaltaan tapahtuvan tasaisen kuumenemisen.

Samoinkuin aikaisemmissa tutkimuksissa (KYTI et al. 1968 c) olivat näissäkin töissä kaikki salmonellakokeet kielteisiä.

Kuten edellä on mainittu tehtiin mikrobiologisten kokeiden rinnalla koesarja, jossa munamassaan lisättiin $0.05,0.1$ tai 0.2 paino $\%$ Na-bentsoaattia bentsoehapoksi laskettuna. Nämä lisäykset eivät kuitenkaan vaikuttaneet millään tavoin munamassan säilytyskestävyyteen $6^{\circ} \mathrm{C}$ :ssa säilytettäessä.

\section{Ti ivistelmä}

Ulkomaisten tutkimusten mukaan munamassan vatkautuvuus huononee ja vaahdon ominaisvolyymi (ml vaahtoa/g massaa) pienenee kun massaa pastöroidaan tai jäädytetään. Kun samanaikaisesti kuitenkin vaahdon säilyvyys paranee tulee valmiin kakun volyymi yhtä suureksi raaka-aineen käsittelystä riippumatta.

Edellä esitetyissä munamassoja käsittelevissä tutkimuksissa ei ole saatu esille mitään mainittavia eroja munien, pastöroimattomien tai pastöroitujen munamassojen vatkautuvuudessa, vaahdon ominaisvolyymissä tai vaahdon säilyvyydessä. Massan jäädyttäminen on sensijaan alentanut vaahdon ominaisvolyymiä mutta toisaalta parantanut huomattavasti vaahdon säilyvyyttä. Kun pastöroitua ja jäähdytettyä massaa varastoitiin $-25^{\circ} \mathrm{C}$ :ssa alkoi vaahdon ominaisvolyymi pienentyä edelleen kolmannen säilytyskuukauden lopulla ja $8 \mathrm{kk}: \mathrm{n}$ kuluttua se oli pienentynyt noin puoleen siitä mitä oli pastö- 
roidun jäädyttämättömän massan ominaisvolyymi, Pastöroimattomalla massalla tämä ominaisuus säilyi muuttumattomana.

Mikrobiologisten tutkimusten perusteella voidaan pastöroimattoman massan sanoa olevan hygieenisesti erittäin arveluttavan tuotteen. Sensijaan pastöroitua ja $6^{\circ} \mathrm{C}$ :ssa säilytettyä massaa voidaan pitää terveydelle haitattomana vielä viidentenä päivänä valmistuspäivästä lukien. Nykyisin on siirrytty käyttämään $4^{\circ} \mathrm{C}$ :een säilytyslämpötilaa, joka kirjallisuustutkimusten perusteella varmistaa tuotteen säilyvyyttä.

Natriumbentsoaatin lisäykset $0.05,0.1$ tai 0.2 paino $\%$ (bentsoehapoksi laskettuna) eivät vaikuttaneet tuotteen säilyvyyteen $6^{\circ} \mathrm{C}$ :ssa säilytettäessä.

\section{KIRJALLISUUS}

Garibaldi, J. A., Donovan, J. W., Davis, J. G. \& Cimino, S. L. 1968. Heat denaturation of the ovomucinlysozyme electrostatic complex- A source of damage to the whipping properties of pasteurized egg white. J. Food Sci. 33: 514-524.

Garibaldi, J. A., Lineweaver, H. \& IJichi, K. 1969. Number of samonellae in commercially broken eggs before pasteurization. Poult. Sci. 48: 1096-1101.

Heller, C. L., Roberts, B. C., Amos, A. J., Smith, M. E. \& Hobbs, B. C. 1962. The pasteurization of liquid whole egg and the evaluation of the baking properties of frozen whole egg. J. Hyg. 60: 135-143.

Kaloyeras, S. A., Novak, A. F. \& Watts, A. B. 1962. Heat sterilization of liquid eggs after stabilization treatment with various proteinases. Poult. Sci. 41: 284-288.

Knight, R. A., Mears, K., Parkinson, T. L. \& RobB, J. 1967. The baking properties of pasteurized whole egg. J. Food Technol. 2: 143-167.

Kyti, M., Tuomainen, L. \& Antila, M. 1968 a. Die Zusammensetzung des Finnischen Hühnereies. Maatal.tiet.aikak. 40: 114-125.

Kyti, M. \& Tuomainen, L. 1968 b. Untersuchungen über die Haltbarkeit von Eiern. Ibid. 40: 219-236.

KYTI, M. \& Tuomainen, L. 1968 c. Kananmunamassan mikrobiologinen laatu. Suom. Eläinlääk. 1. 74: 206-211.

Kyti, M., Tuomainen, L., Nikunen, E. \& Uotil., M. 1968 d. Kananmunien mikrobiologisesta laadusta. Suom. Eläinlääk. 1. 74: 297-306.

Lineweaver, H. \& Cunningham, F. E. 1964. Pasteurizing egg white. U.S. 3,251,697 (Cl. 99-161) May 17 appl. March 19. Ref: Chem. Abstr. 1966. 65.

MAJEWsKA, D. 1962. Vergleichungsprüfungen des bakteriologischen Zustandes vom pasteurisierten und unpasteurisierten Gefriervollei. Symposium of the world association of veterinary food-hygienists. Proceedings Nice, France, May 27 - June 2, 1962. pp. 254-257.

Miller, C. \& Winter, A. R. 1950. The functional properties and bacterial content of pasteurized and frozen whole eggs. Poult. Sci. 29: 88-97.

Nakamura, R. 1966. Foaming property of chicken egg white. Nippon Nogei Kagaku Kaishi 40: R 13-R 18. Ref: Chem. Abstr. 1966, 65: $4539 \mathrm{~g}$.

Palmer, H. H., IJichi, K., Cimino, S. L. \& Rofr, H. 1969. Salted egg yolks. 1. Viscosity and performance of pasteurized and frozen samples. Food Technol. 23: 1480-1485.

Parkinson, T. L. 1966. The effect of heat and other factors on whole egg and its constituents. J. Sci. Food Agric. 17: 233-237.

-» - 1967. Effect of pasteurisation on the chemical composition of liquid whole egg. I-Development of a sheme for the fractionation of the proteins of whole egg. Ibid. 18: 208-213.

REINCE, W. C. \& BAKER, R. C. 1966. The effect of pasteurizing liquid whole egg on viscosity, $\alpha$-amylase and Salmonella senftenberg. Poult. Sci. 45: 1321-1327.

Sugrhara, T. F., IJichi, K. \& KLine, L. 1966. Heat pasteurization of liquid whole egg. Food. Technol. 20: $1076-1083$.

Wood, E. C. \& Young, M. 1969. The keeping quality of pasteurized egg. J. Appl. Bact. 32: 403-407. 